\title{
Mediatization of life: Exploring the influence of the mobile and other media in Nigeria
}

\author{
Allwell Okechukwu Nwankwo*, Silk Ugwu Ogbu** \\ *School of Media and Communication, Pan-Atlantic University, Lagos, Nigeria \\ ** School of Media and Communication, Pan-Atlantic University, Lagos, Nigeria.
}

Abstract

\begin{abstract}
As the $21^{\text {st }}$ Century continues to engender amazing innovations in the communication space, the influence of the media is becoming more pervasive. Thus, the media can no longer be studied separately from society; rather they must be seen as an integral part of the social structure upon which modern societies rest. Mediatization, as a theory, explains the manner in which social institutions are affected by, and seek to adapt to, the media. This paper seeks to contribute to the scholarly discussion of mediatization as a concept. It discusses its applicability within the Nigerian context and considers its implications for society. Using a mix of literature review and comments based on the authors' observation, it discusses and interrogates the mediatization of the contemporary Nigerian society.
\end{abstract}

Keywords: Mediatization, Nigerian media, Nigerian society, media effects, media influence

\section{Introduction}

The ubiquity of the media is an undisputable reality of our times. Their presence has become palpable in every part of the society. The contemporary world is certainly a mediated one and the media appear to be a shaper of reality in many aspects of daily living. Kellner (1995) articulates the situation thus:

Radio, television, film, and the other products of the culture industries provide the models of what it means to be male or female, successful or a failure, powerful or powerless. Media culture also provides the materials out of which people construct their sense of class, of ethnicity and race, of nationality, of sexuality, of "us" and "them" (p.1)

If Kellner (1995) were to be writing today, he would certainly include the internet and the mobile phone as major contributors to contemporary media culture and the ultimate mediatization of society. According to Hjarvard (2008) the media were traditionally studied as entities separate from society and the focus of scholars was to unravel the effects discrete media messages had on individuals and social institutions. To him, this situation is no longer tenable today. The media have so much permeated society that they can no longer be studied as separate from social institutions; rather they are to be understood as part of the sociological architecture of the modern society (Hjarvard, 2008). A look at the contemporary Nigerian society indicates that it is, no doubt, a mediatized one. Social relations, social behavior and various social institutions submit themselves to the logic of the media. Individuals and organizations are becoming more interested in media content, but not just in the passive consumption of messages but also in the creation and dissemination of media products. This paper examines the concept of mediatization within the Nigerian context as a potential template for understanding the 
dynamics in other African societies and explores the different ways developing countries can manage the effects of mediatization as players in the proverbial "global village."

\section{Mediatization Defined}

Mediatization has gained currency as a very important concept among scholars who wish to understand the influence the media exert on society, a situation that has spawned numerous conferences, books, seminars, articles and case studies (Ampuja, Koivisto \& Valiverronen, 2014). The theoretical immanence of the concept can be deduced from the multiple locales of its emergence and development which includes Germany, the Nordic countries, the United Kingdom and some international scholarly collaboration (see Krotz, 2017). The debates it has engendered also position it as a concept too important to be ignored by both its proponents and opponents. We shall return to the debates presently. As a term, "mediatization" has been regarded as "ungainly" and "awkward," especially to the trained ear of a native English speaker; yet this terminologically strange animal can be justified if it helps scholars of varied backgrounds understand the common issues of their discipline (Couldry \& Hepp, 2013). Hjarvard (2008) defines mediatization as "the process whereby society to an increasing degree is submitted to, or becomes dependent on, the media and their logic." He further characterizes this process as inherently dualistic as the media have not only become an integral part of the activities of other institutions but have also attained the status of social institutions on their own. He submits that "media logic" is a referent of the technological and institutional operational methods of the media, including the way they gather and distribute information within certain parameters or rules. Thus, media logic - or the media's modus operandi - influences the very content of communication, the nature of social relations and the sender and receiver of messages. The extent of this influence may vary from one society to another. Stromback (2008) further develops the concept of media logic to mean "the dominance in societal processes of the news values and the storytelling techniques the media make use of to take advantage of their own medium and its format, and to be competitive in the ongoing struggle to capture people's attention." With specific reference to the mediatization of politics, he identifies some of the techniques inherent in media logic to include simplification, polarization, intensification, personalization, visualization, stereotypization, and the framing of politics in particular ways. Submitting to the logic of the media, therefore, implies a conscious effort by society or its institutions not only to depend on the media for communicative purposes but also to design or frame communication in terms that conform to the media's modus operandi. According to Hjarvard (2008), when politicians frame or polarize issues in such a manner as to give them a better chance of being covered by the media, they are simply submitting to the logic of the media. Also in the corporate world, organizations submit to the logic of the media by organizing events or issuing press releases that place emphasis on those issues and developments that they consider to be of interest to the media. A fairly simpler way of conceptualizing mediatization is to regard it as a situation in which "other institutions to an increasing degree become dependent on resources that the media control, and they will have to submit to some of the rules the media operate by in order to gain access to those resources" (Hjarvard, 2008). Thus in a mediatized world, the logics of other social institutions are influenced by the logic of the media (Hjarvard, 2013). 
As mentioned earlier, Hjarvard (2008) points out that although there was a time the media were seen as distinct from culture and society, such a distinction no longer has merit in the contemporary world. His reason is that both society and culture have been so permeated by the media that separating the media from society and culture is no longer helpful. To him, the key task should be a desire to understand how social and cultural institutions have metamorphosed in response to the pervasive influence of the media. According to Krotz (2017) who, by the way, spells the concept as "mediatisation," the approach emerged as a result of the transformations that the media themselves were going through as a result of the embeddedness of the computer infrastructure in media systems and the corollary transformative impacts these were having on everyday life. These impacts were noticeable at the micro, mezzo and macro levels such that the media were becoming central to everyday human activities. It is in the light of these transformations that Krotz conceptualizes mediatization as "the concept of the reconstructive analysis of today's media-related transformations, together with respective social transformations of everyday life, culture and society."

To contextualize the criticality of mediatization as a theory of the role of the media within society and culture, Hjarvard (2013) clearly distinguishes it with, and conceptually demarcates it from, the two research paradigms that have dominated communication studies. The first, is the "effect paradigm," which tends to study the influence of the media by researching "what 'the media do to people"' (p.2). The second paradigm is audience research which situates the influence of the media in the context of the ways people use the media or "what 'people do with the media'." Significantly, both paradigms seek to situate the influence of the media within the context of specific media messages or communicative events as they relate to individuals or a group of individuals. These paradigms, no doubt, are valid approaches to the study of the influence of the media. They have had their day - and perhaps still have a role to play in the field of media studies for a long time to come. This paper, however, adopts the view that these paradigms take a narrow or micro view of media influence by casting the issues in an atomistic mould. On the other hand, mediatization takes a macro view of media influence on society and culture. It does not seek to situate media influence within the narrow confines of specific messages but seeks to unravel the transformational role of the media in reconstituting social relations and interactions between various institutions of society, thus defining social reality and changing patterns of social intercourse (Hjarvard, 2013).

It is important to point out that mediatization is not yet a neat theoretical construct, with consensual acceptance by scholars (Krotz, 2017). It has its critics. Significantly, even among its proponents, there exist divergent views about the "emergence and development of the mediatization process," the discourse of which Deacon and Stanyer (2014) have reviewed. In fact, it has been suggested that despite attempts at empirically grounding the concept, most of the research has relied on "presumption rather than a demonstration of historical change" (Deacon \& Stanyer, 2014).

In a way, Hjarvard's (2008) approach constitutes a reasonable ground on which to assay a discussion of a theory of the influence of the media in contemporary Nigerian society. Rather than deny or de-emphasize the influence of the media in the contemporary world, a quest for a deeper comprehension of media culture and its embedded signification appears to be a more pragmatic strategy. The question may arise: how can we measure mediatization? It is important to state that the purpose of the mediatization theory is not to quantify the influence of the media on social institutions. It is a analytical framework for explaining social reality. As a "high-level societal metaprocess," mediatization and its claims are to be grounded in evidence but may not be amenable to 
"event-event causation" experimental protocols in the same way nobody seeks to test the claims of globalization and individualization (Lunt \& Livingstone, 2016). This argument rests on putting mediatization on the same pedestal as globalization and individualization. This valorization of the concept has been regarded as "not legitimate" while the thinking that mediatization constitutes a paradigm shift has been regarded as "imperialistic and hubristic" (Deacon \& Stanyer, 2015). Our purpose here is neither to recount, nor participate in, the debate, but simply to signpost the existence of a critical scholarship that perceives mediatization differently. For a review of the robust debate, Deacon and Stanyer (2014, 2015), Hepp, Hjarvard and Lundby (2015), Lunt and Livingstone (2016) constitute a fair start. From the debates, some clear viewpoints that merit attention emerge. First, mediatization needs a definite conceptualization in order to save it from becoming everything to everyone. Second, claims of mediatization need to be evidentially solid even if not at granular level. Third, scholarship can be media-centred without becoming media-centric; the point is that the mediatization is an open concept that itself also draws from other social metaprocesses (Krotz, 2017). In fact, it has been suggested that, rather than a metaprocess itself, mediatization should be viewed as a process that exists within the metaprocesses like globalization, individualization, commercialization, enlightenment, liberalism, capitalism and industrialization (Kortti, 2017). Fourth, social change results from the interplay of several forces, of which the media constitute one. Any attempt to privilege the media as the ultimate source of social transformation only falls for a simplistic - even deterministic - account of social flux. Our submission is that, despite the conceptual shortcomings pointed out by its critics, mediatization remains an analytical lens through which to view the omnipresence and influence of the media in various facets of society. In fact, in historicizing mediatization, Krotz (2017) points out that it is a broad, long-term process that has been there all along in various societies depending on socio-environmental factors and it could be applied to account for historical developments in media and communication.

\section{Mediatization of Everything}

As has been noted, the media have become omnipresent institutions whose large footprints etch the sands of society and culture. A number of studies and scholars have sought to cast a sweeping glance at the aspects of life that have been mediatized - and the list seems endless. Hjarvard (2008) points out aspects of life that have witnessed a substantial influence of the media in the way they are organized. Some of these include: politics, culture, human communication, conflict, marketing and consumer culture, research, education, science and sociology, among others. Even the upbringing of children within the family context has also received some form of influence from the media. According to Johan Fornas (cited in Kaun \& Fast, 2014): In all fields of culture, the presence of the media changes the rules of aesthetic creation, dissemination and the use of sound, images and texts. To a high degree, mediatization affects reading, the book industry and the school, listening and the music industry, the theater, film and visual culture in both fine-arts and popular culture (p.10).

In a similar vein, Hjarvard and Petersen (2013) note the complete permeation of cultural practices by the media, which has put the mediatization of culture on the same pedestal as the globalization and commercialization of culture. They opine that this trio has brought everyday culture and high art into new social contexts, not only making them accessible to a greater number of people, but also transforming the nature of the cultural practices 
referred to. In a rather interesting synoptic work, Kaun (2014) summarizes the works of various scholars who have studied the mediatization of distinct facets of life. Although we may not be able to review the summaries, it suffices to note that the impact of mediatization continues to engage the interest of scholars, especially as it pertains to issues as diverse as identity, migration, sexuality, body, gender, morality, norms and values. Kaun (2014) also identifies some of the studies focused on how new practices have developed around the use of media such as the mobile phone and the internet - two media forms that have, in the last few years, become embedded in the daily lives of people and will most likely continue to fan the embers of mediatization in the years to come. This article discusses these issues from the Nigerian standpoint. It explores the manner in which mediatization reconstitutes the interplay of the media and other social institutions, with consequences for society. In that regard, it uses a review of relevant literature and the personal observation of the authors to illustrate and interrogate the implications of the mediatization of the Nigerian society.

\section{The Nigerian Media Landscape}

Some fairly recent studies have indicated that Nigeria has about 150 daily newspapers, a good number of which are community-based (Okoro 2012), 164 radio stations and 135 television stations (National Bureau of Statistics, 2010). At the same time, there are over 150 million mobile phone connections (NCC, 2016) owned by 86 million unique subscribers (GSMA, 2016). Doubtless, the mobile phone has become an essential communication device. Although it was originally made for speech communication, the mobile phone of today is used for various purposes which include accessing other media and even the practice of journalism (Clark, 2013). Moreover, contemporary media culture is now characterized by technological convergence, individualized interactivity and mobility (Drotner, 2005; Tobias, 2015), driven largely by the mobile phone. This state of affairs virtually positions the mobile phone as a culmination of mediality, perhaps a "super medium." It is the view of this paper that the pervasive use of the mobile phone worldwide best exemplifies the mediatization of our world. This is more so when it is considered that virtually all the media converge seamlessly on the mobile phone. It is pertinent, therefore, to explore further the saliency of the mobile phone in the contemporary society

Indeed, the mobile phone is perhaps the most pervasive personal possession in the entire universe (Jayawardhena, Kuckertz, Karjaluoto\&Kautonen, 2009). Although originally designed for mere speech communication between people, advances in technology have invested it with additional capabilities such short message service (SMS), multimedia messaging (MMS), web browsing, mobile TV, navigation and video calls (Jayawardhena, Kuckertz \& Karjaluoto, 2009). It will be quite in order to expect newer mobile phone models to sport additional functionalities and capabilities that would dwarf the really "modest" computing powers of the mainframe computers of the 1980 s.

The mobile phone has become an intimate personal object, that is lightweight and always in the company of the owner. "Nomophobia" (no mobile phone phobia) is the neologism for the addiction to the mobile phone (Piper, 2013). A recent report indicated that on the average, a mobile phone user checks their device at least 150 times daily, while over 500 million pictures taken with cellular phones are shared daily online (Stern, 2013). Some people keep their phones very close to their body, including in brassieres, head scarves and pockets (Flavio, 2015). There is no doubt that the mobile phone has become such an important part of daily life that some people 
have reported that they would feel uneasy or anxious if they went out without their phone, and would most likely return home to fetch it (Sugiyama, 2013). Indeed, a growing number of studies indicate that the mobile phone is increasingly being considered a part or an extension of the user's body (Campbell, 2008; Campbell and Park, 2008; Fidalgo, Telleria, Carvalheiro, Canavilhas and Correira, 2013; Ilharco, 2007; Sugiyama, 2013). This is not entirely unprecedented in the conceptualization of media influence. McLuhan (1994) had stated that "all media are extensions of some human faculty - psychic or physical." As a medium of communication, the mobile phone has become increasingly indispensable. Indeed, it can be described as one of the most conspicuous artifacts in the mediatization of society. This is because the mobile phone is probably the most important medium available to humanity today. Its multiple functions also include sending and receiving messages, shooting videos, taking pictures, accessing the Internet, conducting online banking, among others (Clark, 2013). Owing to its multifunctional nature, the mobile phone enables the distribution and re-distribution of content across other media platforms such as newspapers, magazines, television, radio, movies and books. For a country like Nigeria where nearly $60 \%$ of those with Internet access get connected through their mobile phones (GSMA et al., 2012), the importance of this medium in society cannot be underestimated.

\section{Mediatization of the Nigerian Society}

Hjarvard (2008) regards mediatization as a non-universal process which may not characterize all societies. He views it as primarily a phenomenon that is manifested mostly in "modern, highly industrialized, and chiefly western societies" in Europe, USA, Japan, Australia, etc. Although he posits that with the march of globalization, more cultures and regions will come within the grip of mediatization, there is no strong evidence that Hjarvard's attempt to tie mediatization to industrialization or even the level of development of a given society has an empirical basis, considering that in highly remote areas of Africa, mediatization is redefining social institutions and interactions, through the instrumentality of the mobile phone, even among the uneducated folk. For example, in East Africa, the mobile money service has transformed the concept of money and banking such that even semi-literate populace use their mobile phones to execute all forms of transactions from the purchase of mobile phone credit to payment for consumables. For instance, the mobile phone is widely used in Kenya, although the country is regarded as poor (Mwithia, 2015). The country's mobile phone penetration of $75 \%$ is higher than the Sub-Saharan Africa average of $65 \%$ (Wyche, 2017). Both city and slum dwellers widely use the mobile for various purposes. Perhaps, most significantly, the greatest impact of the mobile in Kenya is on transaction culture. Mobile telephony helped Kenya develop what is, perhaps, the world's most successful mobile payment service, MPESA, which was launched in 2007 by Safaricom (Aker \& Mbiti, 2010).

In Nigeria, as in Kenya, the mobile phone has changed the concept of social interaction from a largely face-toface encounter to a digital experience with about the same measure of immediacy associated with physical presence. For some people, the mobile phone constitutes a "window for seeing the world" and it helps them organize their lives. Today, in Christian religious circles, prayers are not only sent as text messages, but also made through a mobile phone call. Congratulatory messages are now sent through the mobile phone, while husband and wife coordinate their affairs on the mobile phone. Some of these uses of the text messages have been explored by Chiluwa, Chimuanya, Ajiboye and Peter (2015) in their study on the use of the mobile phone 
to build and sustain relationships. Within the family, the media, especially the mobile phone and social media, are equally reconstituting interactions. The mobile phone enables family interaction through social media platforms like Facebook, WhatsApp and Blackberry Messenger, among others. However, the influence of the media on family life and communication is also raising some concerns. There are concerns that the media often interfere with family time together, as the TV, for instance, may not only hinder family interaction but can also be used to avoid talking altogether (Wilson, 2004). In the case of the mobile phone, there is a fear that the constant use of the device creates in family members feelings of frustration, distance and a sense of being ignored (Oduor et al., 2016). Family members often learn about family issues from the media, which projects particular and often unrealistic views of the events. It is also becoming very common for intimate relationships to be formed through social media, the internet or a mobile phone (Khunou, 2012), a development that affects the critical social institutions of marriage and family and often times, putting them in danger. Smith (2006), for instance, demonstrates how the mobile phone is often used to develop and foster pre- and extra-marital sexuality.

Perhaps more significant is the role mobile phones now play at the macro level. We will take a quick sample of studies exploring this. Baro and Endouware (2013) capture the situation in these terms: "When you stand at a busy Lagos street corner for 10 minutes, you cannot count the number of commuters and pedestrians both making or receiving calls and those engaging in retailing recharge cards. Mobile telephony is one of the information and communications technologies (ICTs) that is reshaping and revolutionizing communication in an increasingly global village." In their study of the Niger Delta region of Nigeria, they reported that even people living in rural communities were increasingly depending on the mobile phone to communicate with family and friends, support their livelihoods, access the internet and interact with contacts on social media, among other things. In a similar study, Ogunniyi and Ojebuyi (2016) explored the use of mobile phone by farmers in some South-West states of Nigeria. The farmers reported that their incomes had improved owing to their use of the mobile phone to reach buyers (which reduced transport cost and time), access market information, purchase agricultural inputs and obtain information on new farming methods. Gilbert's (2018) ethnographic account of the mobile phone culture of Calabar's young ladies reveals, on its part, a complex tapestry of youthful dexterity in creating and recreating their worlds both within and away from the quotidian realities of their socio-economic milieu. To such youth, the mobile becomes a connector that, at the same time, affords the user the freedom to create a healthy distance in relationships. Earlier, Smith (2006) had studied the use of the mobile phone in South-East Nigeria as a status marker, negotiator of social praxis and a business enabler. In concrete terms, the mobile phone has also contributed to the mediatization of the Nigerian public space, a topic that has received little attention in scholarly discourse. The reality is that the Nigerian public space has become a mediatized one as the mobile phone appears to have become a frontstage object at public gatherings, used in various ways by different people for various purposes (Adesugba, 2017). Interestingly, people effortlessly use their mobile phones without seeking the permission of those around them (Adesugba, 2017). Again, in Nigeria today the mobile phone has also become an enabler of participatory democracy. Olokesusi and Aiyegbajeje (2017) show clearly how electronic communication devices, especially the mobile phone, have permeated the political process right from electioneering campaigns through election monitoring to post-election project monitoring in a metropolis like Lagos. The mobile phone can now be deployed in various ways to serve the purpose of democratic governance. Sadly, it can also equally be used for selfish manipulations of the democratic process. 
In Nigeria, the mediatization of the society is visible even to the casual observer. Let us briefly consider the case of the social media. According to Africapractice (2014) "social media practices have materialized in unprecedented capacities. They've led to revolutions, encouraging the demand and monitoring of best practices during elections and are also contributing to a larger dynamic of promoting growth on the continent through accountability and conversation." The same study notes that over 50 million Nigerians have access to the Internet, 72 percent of whom were already active on social networking sites as at 2013. So how impactful have social media been? Let us take a closer look. When the government of President Goodluck Jonathan unilaterally removed fuel subsidy on new year day in 2012, Twitter, a social media platform, was used as a mobilization tool for the 'Occupy Nigeria' protests (Africapractice, 2014), which eventually got the government to reverse itself. Similarly, in 2011, a mobile app, 'Revoda', was successfully used to monitor the general elections in order to make them free, fair and transparent (Africapractice, 2014). The perceived impact of the social media has been such that a lot of sub-national governments and politicians now use them as engagement platforms for reaching their target constituents. Furthermore, it has transformed the practice of journalism as many journalists engage with their audience through social media while the practice of citizen journalism has equally blossomed (Africapractice, 2014). The concept of citizen journalism is an offshoot of the ubiquity of the media and the availability of inexpensive content sharing tools. This is also a case of mediatization, which has now turned the audience into the gatherer and disseminator of information (Anaeto, 2011). With just a mobile phone, the citizen journalist has a note-taking device, a voice-recorder, a camera and video-camera all rolled in one. Aside their professional training, the professional journalist could hardly have been better equipped. Perhaps the influence of the media and citizen journalism can be illustrated by the uncanny story of Olajumoke Orisaguna, the Nigerian bread seller who turned a celebrity (Ayo-Adeusi, 2016). Olajumoke, with her "pyramidal" load of bread was caught by TY Bello, popular Nigerian photographer, during a photo shoot with a hip-hop artiste in Lagos. Fortuitously, Olajumoke's picture became an instant rave when it hit the social media. The virality of the Internet propelled the illiterate, struggling bread-seller into overnight stardom as a model. She became rich instantly. This type of rags-to-riches story would have been far-fetched even 20 years earlier. Olajumoke's story illustrates the way social media reconstitutes social relations and levels the playing field for different actors from different social strata.

From the political angle, it could be argued that the mediatization of politics in Nigeria even preceded such developments in the West. The Nigerian press was in the vanguard of the fight for the country's independence and played a prominent role in conscientizing and mobilizing Nigerians toward the fight for independence from the colonialists. Although they probably did not set out to do so, Ibraheem, Ogwezzy-Ndisika \& Tejumaiye (2015) appear to support this position. Their account of the struggle for independence and the post-independence role of the Nigerian media clearly identified Nigeria as a front-runner among mediatized societies. Equally significant is the fact that the coming of the internet and social media has transformed not only politics but also governance. Politicians and public office holders are increasingly giving account of their stewardship to the masses over the social media. Many political leaders in Nigeria now have social media accounts, including the president, Muhammadu Buhari. Buhari's twitter handle (@MBuhari) indicates that he joined twitter in December 2014. As of February 10,2018, he had tweeted 2,700 times (averaging over two tweets per day). He also had over over 1.3 million followers. What does he tweet about? He uses Twitter as a "public journal" of his daily activities and often expresses his opinion on certain issues, such as the hardship Nigerians are facing. Although it could be 
argued that there is a retinue of aides who attend to the president's Twitter account, the fact remains that the platform offers Nigerians the kind of direct access to the office of the president that they could not have imagined possible even as recently as the early 1990 s.

The course of education has also changed through the instrumentality of the media. In Nigeria, online courses are becoming popular: people can now hold on to their day jobs while studying at their own pace. The mediatization of fashion is another angle that merits some exploration. In a study carried out to understand the (non-)use of aso-oke, the traditional Yoruba fabric, among the youth, one reason adduced for the poor performance of the fashion item in comparison with Ankara is that aso-oke is not projected through the media (Olutayo \& Akanle, 2009), which implies that young people often take their fashion cue from the media.

Finally, it will be appropriate to discuss, albeit briefly, the influence of the media in the entertainment scene, with particular reference to music. There was a time in Nigeria when the airwaves were filled with foreign music. Today, through the influence of the media, Nigerian music is now played almost exclusively on the country's airwaves. This has helped shore up the popularity of Nigerian artistes even in foreign lands.

\section{The Implications for the Nigerian Society}

The mediatization of the Nigerian society has both positive and negative implications. On the positive side, it helps drive openness and accountability within the public sphere. The use of social media and its growing popularity within governance circles is creating more pressure for public officials to explain to their constituents how they are managing the nation's affairs. This pressure receives additional impetus with the growing practice of citizen journalism. At the same time, the openness associated with the mediatization of so many facets of society is not only convenient but also provides a level platform for the ventilation of alternative opinions in public discourse. However, citizen journalism has its drawbacks, especially with respect to the issue of source credibility. Some fairly recent examples will drive this point home. In Nigeria, rumors of the death of some public figures often go viral on social media only for the stories to turn out to be false. Also, in the wake of the Ebola Virus attack that hit Nigeria and other West African countries in 2014, a practical joke sent by someone to a friend claiming that bathing with, and drinking, salt water could cure the disease went viral (Filani, 2014). As a result, two people died and 20 were hospitalized for excessive ingestion of salt (Onyeonoro, Ekpemiro, Abali \& Nwokeukwu, 2015).

There is no doubt that at the level of the family, mediatization could support a multi-pronged approach to interactions. It can create a sense of reassurance and perpetual connectedness. Unfortunately, as has been mentioned, such a heavy infusion of the media into family life could also create problems as certain members may feel ignored or abandoned. It may also put more stress on the institutions of marriage and family. In the area of education, the mobile phone and social media can be productively used to enhance academic outcomes through online exchange of ideas and the use of educational applications. At the same time, these platforms could be abused. It has been argued that mobile phones can distract students. A study in Taraba State of Nigeria indicated that students were distracted from their studies by heavy mobile phone use (Rabiu, Muhammed, Umaru \& Ahmed, 2016). The same study also discovered that the students were using their mobile phones to download pornographic content. Such behaviour adversely affects academic outcomes and the moral compass of the 
students. Finally, the mediatization of politics throws up some ethical issues. It may mean that only the vociferous get heard. Those who fail to push or frame their agenda aggressively through the media may lose out even if they have the best solutions to society's problems. In a mediatized world, the ability to frame issues in a manner that synchronizes with the media logic can easily become a critical game-changer.

\section{Conclusion}

By all accounts, the Nigerian society is a media suffused one. Most importantly, the media have also become a veritable means of organizing other social institutions and coordinating their roles within society. These other institutions - politics, education, family, religion, business, among others - appear to have submitted to the logic of the media, with consequences that could be favorable or unfavorable to society. Significantly, the advent of the Internet, mobile phone and social media has largely transformed the conceptualization of the media and their role within society. As new technologies are developed, it is to be expected that the role of the media as social institutions and their influence will keep evolving. There is no doubt that, with time, more facets of Nigerian life will become mediatized.

A deep understanding of the consequences of mediatization can inform institutional response at various levels to harness the positive outcomes of mediatization while minimizing the negative ones. It is important that policy makers understand the implications of the expanding influence of the media and how they are impacting individual behavior and institutional performance so that they can develop proactive strategies for dealing with the situation. As social institutions realign their basic functions to fit the mediatized society and citizens become journalists (concerned more with capturing moments with their camera phones and transmitting same via the social media rather than experiencing or enjoying them), the power of the media is most likely going to rise. Across the length and breadth of Africa, the story is more or less the same. Mediatization is sweeping through traditional African societies like a hurricane while leaders are watching from their mobile phones and other media. The emergence of satellite television and digital media platforms has eliminated geographical walls and all forms of barriers to media content. Nigeria and many other African countries are swamped daily with content from Europe, America and Asia. The battle for cultural supremacy has been on for years on the airwaves. Unfortunately, Africa often appears to be fighting with machetes and arrows when the rest of the world is deploying advanced weaponry. Without a conscious and coordinated effort to tell its own story or propagate its culture to the world, Africa will continue to consume media products from other continents that denigrate its values, or serve as the dumping ground for all kinds of content distributed via the internet and digital media. Given what we know about mediatization today, this development may portend grave danger for the future, especially with regard to the preservation of indigenous traditions. To a great extent, it appears there is no coherent strategy or government initiative driving the media industry in Nigeria. The modest successes of some media organizations, 'Nollywood' and music pop stars are largely attributable to individual endeavors rather than any deliberate plan or government policy. The authors of this paper believe that the stakes are too high for the government to ignore the media sector (broadly defined) and its pervasiveness. Effort should be made to articulate a comprehensive strategy that will guarantee homeostasis. Apart from managing and moderating the engagements between social institutions and the media, government should provide direction and adequate 
support to content producers as a way of promoting the culture of traditional societies or defending indigenous values from negative influences. While there are many positives that can be derived from the Western culture, most people will, for instance, agree that the sagging of trousers by teenage boys that is currently trending across African societies is definitely not one of them. Since it may be difficult to control the internet or restrict access to the information superhighway, it is imperative that Nigeria, and indeed the whole of Africa, devise other practical methods, including the production and distribution of counter narratives embedded in compelling content, for dealing with the challenges of a mediatized world.

\section{References}

Adesugba, A. (2017). An ethnographic study of mobile phone users in public places in Nigeria. Journal of Scientific Research and Studies, 4(11), 282-192.

Africapractice (2014). The social media landscape in Nigeria 2014: The who, the what and the know. Available at: $\quad$ http://www.africapractice.com/wp-content/uploads/2014/04/Africa-Practice-Social-MediaLandscape-Vol-1.pdf

Aker, J. C. \& Mbiti, I. M. (2010). Mobile phones and economic development in Africa. CGD Working Paper 211, Washington, D.C., Centre for Global Development. Available at: http://www.cgdev.org/content/publications/detail/1424175.

Ampuja, M., Koivisto, J. \& Valiverronen, E. (2014). Strong and weak forms of mediatization theory: A critical review. Nordicom Review, 35, 111-123.

Anaeto, S.G. (2011). Citizen journalism: Challenges, prospects and implications for media practice. In E. Biakolo, J.T. Tsaaior, A. Tam-George \& A. Agina (Eds.), Journalism and new media technologies in Africa (pp.172188). Lagos: Centre For Black And African Arts And Civilization.

Ayo-Adeusi, D. (2016). Olajumoke Orisaguna: Find out the untold story of Nigeria's favorite cover girl. Available at: http://pulse.nq/fashion/olajumoke-orisaquna-find-out-the-untold-story-of-nigerias-favorite-covergirl-id4662175.html

Baro, E.E. \& Endouware, B.C. (2013). The effects of mobile phone on the socio-economic life of the rural dwellers in the Niger Delta Region of Nigeria. Information Technology for Development, 19(3), 249-263.

Campbell, S. (2008). Mobile technology and the body: Apparatgeist, fashion and function. In J. Katz (Ed.), Handbook of mobile communication studies (pp. 153-164). Cambridge, Massachusetts: The MIT Press.

Campbell, S. \& Park, Y. (2008). Social implications of mobile telephony: The rise of personal communication society. Sociology Compass, 2(2).

Chiluwa, I., Chimuanya, L., Ajiboye, E. \& Peter, A. (2015). Texting and relationship: Examining discourse strategies in negotiating and sustaining relationships using mobile phone. Covenant Journal of Language Studies (CJLS), 3(2), 15-38.

Clark, B. (2013). Cellular phones as primary communications devices: What is the implication for a global community? Global Media Journal. Fall.

Couldry, N. \& Hepp, A. (2013). Conceptualising mediatization: Contexts, traditions, arguments. Communication Theory, 23 (3), 191-202. 
Deacon, D. \& Stanyer, J. (2014). Mediatization: Key concept or conceptual bandwagon. Media, Culture \& Society, 36(7), 1032-1044.Deacon, D. \& Stanyer, J. (2015). 'Mediatization and' or Mediatization of'? A response to Hepp et al. Media, Culture and Society, 374), 655 - 657.

Drotner, K. (2005). Media on the move: Personalized media and the transformation of publicness. Journal of Media Practice, 6(1), 53-64.

Fidalgo, A., Telleria, A., Carvalheiro, J., Canavilhas, J., \& Correira, J. (2013). Human being as communication portal: The construction of the profile on mobile phones. Revista Latina de comunicación social, 68.

Filani, K. (2014). Nigerian lady who started the salt \& water ebola cure rumour tenders apology. Available at: http://www.kemifilani.com/2014/08/nigerian-lady-who-started-salt-water.html

Flavio, A. (2015, February 23). Cell phones damage your body parts. Available at: http://anonhq.com/body-partkeep-cell-phone-dies-actual-death/

Gilbert, J. (2018). 'They're my contacts, not my friends': Reconfiguring affect and aspirations through mobile communication in Nigeria. Ethnos, 83(2), 237-254.

GSMA - GSM Association, Deloitte, Wireless Intelligence. (2012). Sub-Saharan Africa mobile observatory 2012. Available at: http://www.gsma.com/publicpolicy/wpcontent/uploads/2012/03/SSA FullReport v6.1 clean.pdf

GSMA (2016). Mobile for development utilities: Assessing the opportunity for pay-as-you-go solar in Nigeria. Available at: http://www.gsma.com/mobilefordevelopment/wp content/uploads/2016/02/GSMAFeasibility-Study PAYG-solar-in-Nigeria-Utilities-blog-20160210.pdf

Hepp, A., Hjarvard, S. \& Lundby, K. (2015). Mediatization: Theorizing the interplay between media, culture and society. Media, culture \& society, 1-11.

Hjarvard, S. (2008). The mediatization of society: A theory of the media as agents of social and cultural change. Nordicom review, 29(2), 105-134

Hjarvard, S. (2013). The mediatization of culture and society. Abingdon, Oxon: Routledge

Ibraheem, I.A., Ogwezzy-Ndisika, A.O. \& Tejumaiye, A. (2015). Beyond influence: Media and the 2015 presidential election. Available at: http://www.inecnigeria.org/wp-content/uploads/2015/07/ConferencePaper-by-Ismail-Adegboyega-and-Co.pdf

Ilharco, F. (2007). Where are you? A Heideggerian analysis of the mobile phone. Comunicação \& Cultura, 3.

Jayawardhena, C., Kuckertz, A., \& Karjaluoto, H. K. (2009). Antecedents to permission based mobile marketing: An initial examination. European journal of marketing, 43(3/4), 473-499.

Kaun, A. \& Fast, K. (2014). Introduction: The mediatization of culture and everyday life. In Kaun, A. \& Fast, K. (Eds.) The mediatization of culture and everyday life (pp. 6-18). Karlstad University Studies. Available at: http://sh.diva-portal.org/smash/get/diva2:698718/FULLTEXT02.pdf

Kellner, D. (1995). Media culture: Cultural studies, identity and politics between the modern and the postmodern. London: Routledge.

Khunou, G. (2012). Making love possible: Cell phones and intimate relationships. African Identities, 10(2), 169179.

Kortti, J. (2017). Media history and the mediatization of everyday life. Media History, 23(1), 115-129.

Krotz, F. (2017). Explaining the mediatisation approach. Javnost: The Public, 24(2), 103-118. 
Lunt, P. \& Livingstone, S. (2016). Is 'mediatization' the new paradigm for our field? A commentary on Deacon and Stanyer (2014, 2015) and Hepp, Hjarvard and Lundby (2015). Media, Culture \& Society, 38(3), 462-470.

McLuhan, M. \&. (2001). The Medium is the massage. Corte Madera: Gingko Press Inc.Mwithia, J. (2015). Domesticating the mobile phone in Kiberia: How Nairobi's urban poor are integrating the mobile phone into their everyday lives. Unpublished PhD Thesis. University of Technology, Sydney.

Oduor, E., Neustaedter, C., Odom, W., Tang, A., Moallem, N., Tory, M. \& Irani, P. (2016). The frustrations and benefits of mobile device usage in the home when co-present with family Members. Available at: http://clab.iat.sfu.ca/pubs/Oduor-MobileDevices-DIS2016.pdf

Ogunniyi, M.D. \& Ojebuyi, B. R. (2016). Mobile phone use for agribusiness by farmers in Southwest Nigeria. Journal of Agricultural Extension, 20(2), 172-187.

Olokesusi, F. \& Aiyegbajeje, F.O. (2017). E-democracy for smart city Lagos. In T.M.V. Kumar (Ed.), E-democracy for smart cities: Advances in 21st century human settlements (pp. 51-70). Singapore: Springer Nature

Olutayo, A.O. \&Akanle, O. (2009). Aso-Oke (Yoruba's hand woven textiles) usage among the youths in Lagos, Southwestern Nigeria. International journal of sociology and anthropology, 1(3), 062-069

Onyeonoro, U.U., Ekpemiro, U.C., Abali, C. \& Nwokeukwu, H. I. (2015). Ebola epidemic - Nigerian experience. The Pan-African medical journal, 22(1). Available at: http://www.ncbi.nlm.nih.gov/pmc/articles/PMC4695530/

Piper, R. (2013, November 24). Your cell phone is not part of your body - You can let it go. Available at: http://www.huffingtonpost.com/robert-piper/cell-phone-addiction b 3937062.html

Rabiu, H., Muhammed, A. I., Umaru, Y. \& Ahmed, H. T (2016). Impact of mobile phone usage on academic performance among secondary school students in Taraba State, Nigeria. European scientific journal, 12(1), 466-479.

Smith, D.J. (2006). Cell Phones, Social Inequality, and Contemporary Culture in Nigeria. Canadian Journal of African Studies / Revue Canadienne des Études Africaines, 40(3), 496-523.

Stern, J. (2013). Cellphone users check phones 150x/day and other internet fun facts. Available at: http://abcnews.go.com/blogs/technology/2013/05/cellphone-users-check-phones-150xday-and-otherinternet-fun-facts/

Stromback, J. (2008). The four phases of mediatization: an analysis of the mediatization of politics. Press/politics, $13(3), 228-246$

Tobias, S. (2015). Under the macroscope: Convergence in the us television market between 2000 and 2014 . Image, 22, 4-21

Wilson, B.J. (2004). The mass media and family communication. In Vangelisti, A.L. (Ed.). Handbook of family communication (pp. xiii-xx). Mahwah, New Jersey: Lawrence Erlbaum Associates, Publishers.

Wyche, S. (2017). Exploring women's everyday mobile phone experiences in Nairobi, Kenya. Interacting with Computers, 29(3), 391-402. 